Archived version from NCDOCKS Institutional Repository http://libres.uncg.edu/ir/asu/

\title{
Appalachïan
}

B O O NE, NORTH CAROLINA

\section{How Product-Cause Fit And Donation Quantifier Interact In Cause-Related Marketing (CRM) Settings: Evidence Of The Cue Congruency Effect}

\author{
By: Neel Das, Abhijit Guha, Abhijit Biswas, and Balaji Krishnan
}

\begin{abstract}
We are the first to examine the joint impact of product-cause fit and donation quantifier in the cause-related marketing (CRM) domain. We show that these two CRM cues interact in a unique manner, reflecting the cue congruency effect. Specifically, congruent combinations of these two cues result in high purchase intentions when the cues individually have positive effects. In all other cases, however, purchase intentions are low. Furthermore, we identify moderators of the above cue congruency effect. In Study 1, we show that the cue congruency effect is moderated by product-type, evidencing only in more hedonic product contexts. In Study 2, we show that the above cue congruency effect is moderated by purchase-type, evidencing in planned purchase contexts, but reversing in impulse purchase contexts. We discuss the process mecha- nism driving these effects, specify the contribution of this research for CRM, cue congruency and impulse purchases, and outline implications for practice.
\end{abstract}

Das, N., Guha, A., Biswas, A. et al. Mark Lett (2016) 27: 295. https://doi.org/10.1007/s11002-014-9338-6. Publisher version of record available at: https://link.springer.com/article/10.1007/s11002-014-9338-6 


\title{
How product-cause fit and donation quantifier interact in cause-related marketing (CRM) settings: evidence of the cue congruency effect
}

\author{
Neel Das \& Abhijit Guha \& Abhijit Biswas \& \\ Balaji Krishnan
}

\begin{abstract}
We are the first to examine the joint impact of product-cause fit and donation quantifier in the cause-related marketing (CRM) domain. We show that these two CRM cues interact in a unique manner, reflecting the cue congruency effect. Specifically, congruent combinations of these two cues result in high purchase intentions when the cues individually have positive effects. In all other cases, however, purchase intentions are low. Furthermore, we identify moderators of the above cue congruency effect. In Study 1, we show that the cue congruency effect is moderated by product-type, evidencing only in more hedonic product contexts. In Study 2, we show that the above cue congruency effect is moderated by purchase-type, evidencing in planned purchase contexts, but reversing in impulse purchase contexts. We discuss the process mechanism driving these effects, specify the contribution of this research for CRM, cue congruency and impulse purchases, and outline implications for practice.
\end{abstract}

\footnotetext{
N. Das

Walker College of Business, Appalachian State University, 4097 Raley Hall, Boone, NC 28608, USA e-mail: dasn@appstate.edu
}

A. Guha

Department of Marketing, University of South Carolina, 1014 Greene Street, Columbia, SC 29208, USA

e-mail:abhijit.guha@moore.sc.edu

\author{
A. Biswas (*) \\ Department of Marketing, Wayne State University, 5201 Cass Avenue, Detroit, MI 48202, USA \\ e-mail: A.Biswas@wayne.edu \\ B. Krishnan \\ Fogleman College of Business and Economics, University of Memphis, 3675 Central Avenue, Memphis, \\ TN 38152, USA \\ e-mail:krishnan@memphis.edu
}


Keywords Cause-related marketing · CRM · Donation quantifier · Product-cause fit • Cue congruency $\cdot$ Impulse purchases

\section{Introduction}

Cause-related marketing (CRM) efforts involve firms contributing to a cause/charity each time consumers make a purchase. For example, as part of Kay Jewelers' CRM partnership with St. Jude Children's Research Hospital, Kay Jewelers donated \$4 to St Jude's for each limited-edition teddy bear purchased (Folse et al. 2010). Or, more recently, Energy Muse created a Pure Wrap bracelet in collaboration with People for Ethical Treatment of Animals (PETA) and promised to donate "a portion of the proceeds" from the bracelet to PETA. As is evident in these examples, there are two distinct cues embedded in the firm's CRM efforts. The first cue is product-cause fit, i.e., the degree of "fit" between the Kay Jeweler's teddy bear and St. Jude's, or between the Energy Muse bracelet and PETA. The second cue is donation quantifier, i.e., whether the CRM donation is concrete ("\$4" donated) or vague (donate "a portion of the proceeds").

In this research, we focus on how consumers evaluate these two CRM cues. Fit is the degree of association between a cause and a brand (Lafferty et al. 2004) or a product (Strahilevitz and Myers 1998; Strahilevitz 1999), and in a CRM context, high fit increases consumers' purchase intentions (Pracejus and Olsen 2004). Donation quantifier refers to the framing of the amount going to the associated charity, and in a CRM context, concrete donation quantifiers increase consumers' purchase intentions (Olsen et al. 2003). What is hitherto unexplored is the joint impact of these CRM cues on consumers' evaluations, which is an important research gap and hence the focus of this paper.

We now presage our results. An intuitive prediction would be that both high product-cause fit and concrete donation quantifier positively impact consumers' evaluations (i.e., show positive main effects), independent of each other. Alternatively, another intuitive prediction would be that the two cues positively interact to have a multiplicative effect on consumers' evaluations. However, our first result is that these two CRM cues interact in a very unique, non-intuitive manner, best explained by the cue congruency effect (see Miyazaki et al. 2005). That is, the combination of high fit and concrete donation quantifier leads to consumers expressing high purchase intentions. In other cases (i.e., high fit-vague donation quantifier, low fit-concrete donation quantifier, and low fit-vague donation quantifier), consumers' purchase intentions are lower and similar.

Second, the above interaction result is moderated by both product-type and purchase-type. In the CRM literature, the key product-type difference relates to hedonic versus utilitarian products, with CRM benefits more likely in hedonic contexts (Strahilevitz and Myers 1998). In Study 1, we find that the cue congruency effect evidences only in more hedonic product contexts. Also, impulse buying contexts are emerging as an important research domain (Inman et al. 2009). In Study 2, we demonstrate how the effects of these two CRM cues differ across planned versus impulse purchase contexts. In planned purchase contexts, the data pattern reflects the prior-described cue congruency data pattern. In impulse purchase contexts, however, 
the data pattern reflects a "reverse" cue congruency relationship. Specifically, we find that the combination of low fit-vague donation quantifier leads to consumers expressing lower purchase intentions. In all other cases (i.e., high fit-vague donation quantifier, low fit-concrete donation quantifier, and high fit-concrete donation quantifier), consumers' purchase intentions are higher and similar. In short, in impulse purchase contexts, the cue congruency pattern reverses.

In sum, this research shows that, in CRM contexts, product-cause fit and donation quantifier interact in a unique, non-intuitive manner that reflects the cue congruency effect. Furthermore, this research also identifies moderators of such cue congruency effect. Figure 1 presents a conceptual framework that overviews this research.

\section{Cue congruency effect across more hedonic versus less hedonic products}

In this research, we focus on how consumers respond to two important CRM cues, (1) product-cause fit and (2) donation quantifier. Both these cues are important, reflecting structural elements of the CRM offer, are easy-to-implement, apply to most target consumers, and are wholly under the control of the firm. In contrast, cues like donation proximity (whether the supported charity is local vs. national) and cause involvement may not apply equally to all target consumers, and cues like induced temporal mindset require special conditions or calibrated advertising and are harder-to-implement. However, while researchers have examined the effectiveness of product-cause fit and donation-quantifier in CRM contexts on a solus basis, there is no work (that we could find) that examines how these two cues interact, and if so, how.

Also, given that the most relevant product type difference, in CRM contexts, is the degree of hedonism (Strahilevitz and Myers 1998), we examine if the interaction effects may be (further) modified by product-type (more hedonic vs. less hedonic). We first (briefly) discuss the two individual cues, then hypothesize about their interaction effect (which reflects the cue congruency effect), and finally discuss how such cue congruency effect may be impacted by differences in product-type.

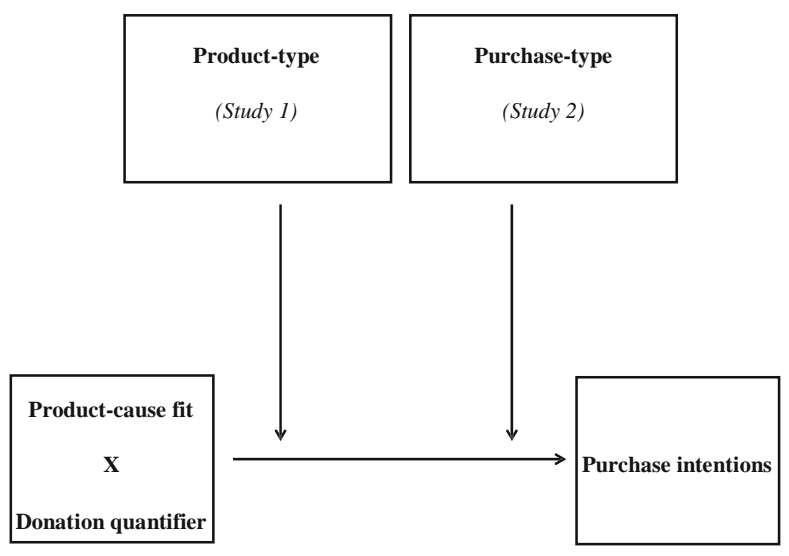

Fig. 1 Research framework 


\subsection{CRM and product-cause fit}

Fit is the consumers' perceived link between the firm's product and the affiliated cause's/charity's image. High fit, for example, could be a book store donating to a Literacy Fund whereas low fit could be a confectionary store donating to a Diabetes Foundation (examples from Strahilevitz and Myers 1998). High product-cause fit, as noted before, increases consumers' purchase intentions (Pracejus and Olsen 2004).

\subsection{CRM and donation quantifier}

Donation quantifier relates to the format in which the amount of the purchase price targeted for the charity is presented to the consumers. The quantifier may vary from a concrete amount (either a dollar amount, or a specific percentage of the price) to a vague/unspecified statement such as "a portion of the proceeds will be donated to the [associated charity]." Concrete donation quantifier increases consumers' purchase intentions (Pracejus et al. 2003).

\subsection{Cue congruency effect (product-cause fit×donation quantifier)}

When considering any purchase, consumers utilize several cues to assess the value of any given option. According to cue congruency theory, a consistent or collaborating pattern among the cues is more useful than a disparate or an inconsistent pattern (Miyazaki et al. 2005, p. 149, Fig. 1). Consistent cues yield a cumulative positive effect. In contrast, when cues are inconsistent, consumers focus primarily on the disparate or negative cue and tend to anchor their evaluation from that perspective (Ahluwalia 2002; Campbell and Goodstein 2001; Herr et al. 1991; Maheshwaran and Chaiken 1991). This tendency to anchor on the negative cue comports with the "negativity bias," which underlies the cue congruency effect. ${ }^{1}$ Cue congruency effect is a special form of a positive interaction and is evidenced via three very specific features (1) a positive and significant interaction, (2) higher evaluations only in the cell with congruent positive cues, and (3) lower, and similar, evaluations across the other cells (Miyazaki et al. 2005; p. 149, Fig. 1, panel A).

The popular press suggests that, today, consumers are more skeptical than ever before (Schumpeter 2014), with trust in brands eroding quickly. More importantly, consumers are aware that firms may resort to "do-good" appeals (e.g., CRM) to boost sales - "innumerable brands argue that the best way to save the planet is to buy their products" (Schumpeter 2014). In such a case, consumers may perceive CRM as merely a ploy to increase sales, i.e., "gimmick named cause-related marketing” (Rogers 2001). In such skeptical environments, the negativity bias is more likely to be salient, with consumers being vigilant about firms' marketing effort. And it is exactly in such

\footnotetext{
${ }^{1}$ The effect of cue congruency is not driven by argument strength. If this were the case, then purchase intentions should steadily increase from (1) the case when both cues are negative (low fit and vague donation quantifier), to (2) a case where one cue is positive (either high fit or concrete quantifier), to (3) the case where both cues are positive. Instead, cue congruency effect derives more from the negativity bias, where purchase intentions are (1) low if any one cue is negative (as the effect of the negative cue dominates) and (2) high only when both cues are positive.
} 
environments that the cue congruency effect-which is driven by the negativity biasis likely to evidence (Miyazaki et al. 2005).

Thus, we posit that the positive interaction pattern across product-cause fit and donation quantifier should reflect a data pattern consistent with the cue congruency effect. High product-cause fit and a concrete donation quantifier represent mutually consistent and reinforcing patterns of positive cues whereas all other combinations include at least one negative cue. If a single negative CRM cue is present (e.g., low product-cause fit or vague donation quantifier), it should overshadow the other positive cue (e.g., high product-cause fit, or concrete donation quantifier), resulting in lower purchase intentions. Consistent with cue congruency theory, therefore, purchase intentions should be (1) high when high product-cause fit is paired with concrete donation quantifier and (2) lower (and similar) in all other cases.

\subsection{CRM and product-type}

The most relevant product type difference, in CRM contexts, is the degree of hedonism (Strahilevitz and Myers 1998), and so we examine if this difference would impact the cue congruency effect proposed above. More hedonic products are multisensory and typically provide for experiential consumption experiences (Khan et al. 2005) and are typically perceived as discretionary consumption (Okada 2005). In contrast, less hedonic products (some may say, utilitarian products ${ }^{2}$ ) are instrumental and motivated by functional needs. Purchase of more hedonic products is typically harder to justify (Khan et al. 2005) and thus have greater associated guilt (Strahilevitz and Myers 1998; Strahilevitz 1999). Such heightened guilt can be mitigated with a contribution to a charitable cause (Strahilevitz and Myers 1998). Put differently, the consumption of a hedonic product gives rise to guilt-ridden emotions, which can be assuaged by a CRM donation. In contrast, consuming less hedonic products has less accompanying guilt, and thus, in less hedonic contexts, CRM donations are less effective. Research has consistently shown that various drivers of CRM effectiveness, like donation size (Strahilevitz 1999), are more beneficial in the case of more hedonic products. Given that CRM cues are more effective for more hedonic products, we posit that cue congruency effects should be more pronounced in the case of more hedonic products. Thus:

$\mathrm{H}_{1}$ : More-hedonic products: Purchase intentions should be highest when the product-cause fit is high and the donation quantifier is concrete. All other cue combinations should yield similar, and lower, purchase intentions.

$\mathrm{H}_{2}$ : Less-hedonic products: No significant difference in purchase intentions across various cue combinations.

\footnotetext{
${ }^{2}$ In this research, we prefer to use the classification "more hedonic" versus "less hedonic" (rather than hedonic versus utilitarian), since the very same product can be classified as either hedonic or utilitarian, contingent on goals and subjective perceptions (e.g., cellphones: Khan et al. 2005; toothpaste: Batra and Ahtola 1991).
} 


\subsection{Pretest}

We conducted a pretest to (1) identify more versus less hedonic product categories and (2) identify causes that would be recognized as having a high versus low fit with these product categories. Participants ( $N=36$ undergraduates) were asked to rate eight products-Gourmet coffee drink, Bottled water, Toothpaste, Kettle cooked gourmet potato chips, Trash bags, Chocolate fudge ice-cream, six-pack toilet paper rolls, and Gourmet deluxe pound cake-and indicate whether each product was more hedonic or less hedonic. Next, participants examined eight charities (Ocean Conservancy, Dare to Care Food Bank, Oral Health America, Water for People, Icing Smiles, Coffee Kids, World Cocoa Foundation, and World Care) and matched charities to products in terms of high versus low fit. Finally, participants also indicated their attitude regarding each charity.

One hundred percent of participants identified the Gourmet coffee drink as being more hedonic, and $94.4 \%$ participants identified Toothpaste as being less hedonic. Additionally, (1) "Coffee Kids" was indicated as having high fit with Gourmet coffee drink (by $100 \%$ participants) and low fit with Toothpaste (by $33.3 \%$ participants - the highest response category; responses of other $66.6 \%$ participants were spread over five products), and (2) "Oral Health America” was indicated as having low fit with Gourmet coffee drink (by $30.5 \%$ participants - the highest response category; responses of other $69.5 \%$ participants were spread over five products) and high fit with Toothpaste (by $94 \%$ participants). Hence, to develop stimuli, we chose the products Gourmet coffee drink and Toothpaste, and we chose the causes Coffee Kids and Oral Health America.

\subsection{Methods and procedure}

For the main study, undergraduate students $(N=214$, females $=46.8 \%$, median age $=21$, cell sizes ranged from 24 to 28) were randomly assigned to a 2(product-cause fit: high vs. low) $\times 2$ (donation quantifier: concrete vs. vague) $\times 2$ (type of product: more hedonic vs. less hedonic) between-subjects study. The stimulus, administered online, portrayed a purchase context with embedded CRM, wherein participants were asked to imagine buying either a Gourmet premium coffee drink (more hedonic product) or a twin-pack Toothpaste (less hedonic product). Both products were priced similarly, at \$5.99, and linked to either Coffee Kids or Oral Health America. Donation quantifier was manipulated by stating that either 60 cents (concrete amount) or "a portion" (vague amount) of the purchase price was to be donated to the target charity.

We assessed the dependent variable, purchase intention, using four items, with an example item being: "How likely are you to buy the ...?" (highly unlikely (1)/highly likely (7)). We also measured attitude towards the charity using the three items, with an example item being: "I have a favorable opinion of ..." (strongly disagree (1)/strongly agree (7)). For both variables, $\alpha$ was $>.9$.

Finally, we asked three sets of manipulation check questions. First, two questions (adapted from Nan and Heo 2007) judged the notion of product-cause fit: "I think that a product in the form of ... donating to the cause of ... represents a good match between the product and the cause"; "I think that donations to the cause of ... are appropriate for the product category of... (strongly disagree (1)/strongly agree (7)), (above, $r>0.7$ ). 
Second, we elicited hedonism assessments for the product evaluated by the participant, by asking "How hedonic do you think is the [Gourmet coffee drink]/[Toothpaste] that you see here" (not hedonic at all (1)/extremely hedonic (7)) and "How utilitarian do you think is the [Gourmet coffee drink]/[Toothpaste] that you see here" " (not utilitarian at all (1)/extremely utilitarian (7)). Third, participants were asked whether there was a specific mention of exactly how much of the purchase price of each ... would go towards the cause of ... with response options "yes" or "no."

\subsection{Results}

All participants correctly responded to the donation quantifier manipulation check question. As expected, the Gourmet premium coffee drink was perceived as being the more hedonic product. Specifically, the difference score [hedonic rating minus utilitarian rating] $]^{3}$ for the Gourmet premium coffee drink averaged 0.83, which was significantly more than the difference score for the twin-pack Toothpaste $(M=-2.10$, $\left.t_{(212)}=9.27, p<0.001\right)$. Furthermore, for the Gourmet premium coffee drink, the charity Coffee Kids was perceived to have a higher product-cause fit $(M=5.52)$ compared with that for Oral Health America $\left(M=3.11 ; F_{(1,100)}=66.33, p<0.001\right)$. For the twin-pack Toothpaste, the charity Oral Health America was perceived to have a higher productcause fit $(M=5.20)$ compared with that for Coffee Kids $\left(M=2.80 ; F_{(1,110)}=89.15\right.$, $p<0.001)$. Finally, attitude measures across Coffee Kids $(M=4.65)$ versus Oral Health America $\left(M=4.34 ; F_{(1,212)}=3.22\right.$, n.s. $)$ were not significantly different. This suggests that differential results across charities could not be attributed to differences in charityrelated attitudes. Overall, the above results suggest that we operationalized our manipulations appropriately.

We next analyzed the dependent variable-purchase intentions. The main effects for product-cause fit, donation quantifier, and degree of hedonism were significant $\left(F_{(1}\right.$, 206) $>3.9, p<0.05$ ), reflecting findings that are consistent with prior work (cited earlier). All two-way interactions were not significant $\left(F_{(1,206)}<3.2, p>0.05\right)$. Most important, there was a significant three-way interaction $\left(F_{(1,206)}=9.53, p<0.01\right)$, and to analyze this interaction, we examined results separately for more hedonic products versus less hedonic products (see Fig. 2).

In the case of more hedonic products, purchase intention was highest for high product-cause fit and concrete donation quantifier $(M=4.33)$, with planned contrasts against all other cells $\left(M_{s} 2.65-2.79\right)$ indicating significant differences, in all cases, $F_{(1,206)}>20, p<0.05$. Furthermore, purchase intentions were not significantly different across the other three cells, with planned contrasts indicating non-significant differences, in all cases, $F_{(1,206)}<1$.This data pattern reflects the cue congruency effect and was consistent with $\mathrm{H} 1$.

In the case of the less hedonic products, however, there were no significant differences across cells, with $M_{s} 2.42-2.97$, in all cases $F_{(1,206)}<2.7, p>0.1$. These results were consistent with $\mathrm{H} 2$.

\footnotetext{
$\overline{3}$ This difference score calculation is consistent with methods in Kronrod et al. (2012).
} 


\section{More Hedonic Product}

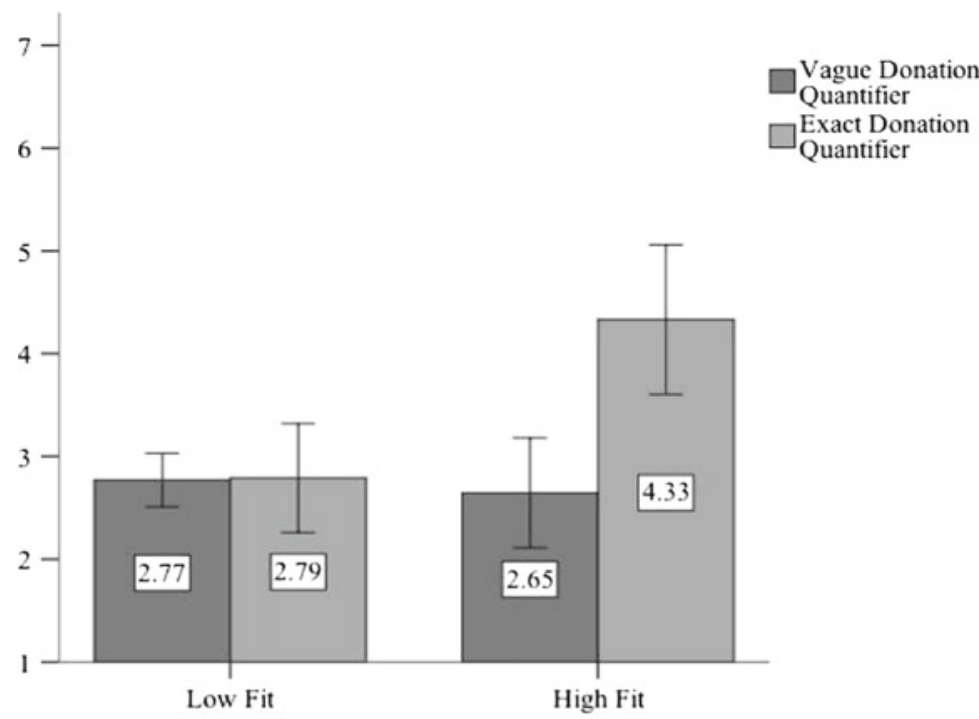

Less Hedonic Product

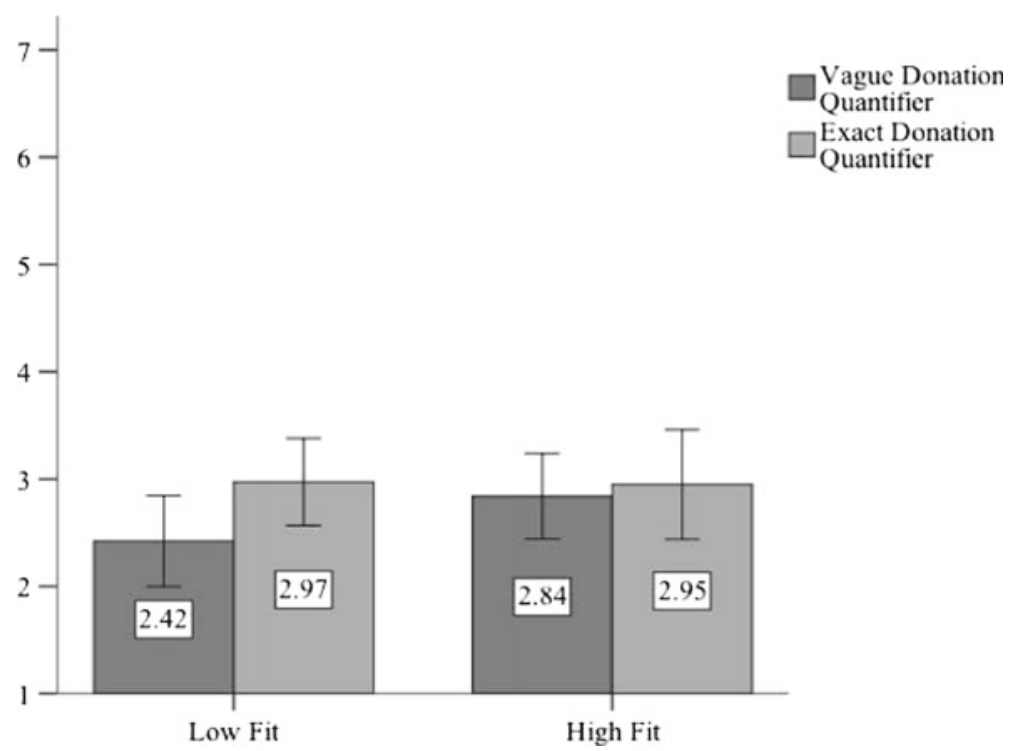

Fig. 2 Study 1 results

\subsection{Replication study}

To examine robustness, we ran a replication online study, using study design, stimuli, and measures generally similar to what we used in Study 1, but using different products/ charities, and a very different participant profile (we used non-student, adult U.S. participants, $N=257$, females $=53.3 \%$, median age $=50$ years). Full details, suppressed for reasons of brevity, are available on request. We replicated Study 1 
results, finding a significant three-way interaction $\left(F_{(1,249)}=7.61, p<0.01\right)$. Exactly as in Study 1, the data pattern was consistent with the cue congruency effect for more hedonic products, but not for less hedonic products.

\subsection{Discussion}

The discerning reader may point out that the cue congruency result evidences in multiple ways. ${ }^{4}$ For example, if we were to consider just the high fit condition, then purchase intentions are highest when the donation quantifier is concrete and the product is more hedonic, reflecting the cue congruency effect. This is consistent with past literature (cited earlier), which suggests that CRM benefits are highest for concrete donation quantifier and more hedonic products. Thus, considering just the variables, donation quantifier and product-type, cue congruency effect across these two variables would be moderated by degree of fit, evidencing only in the high fit condition. Similarly, considering just the variables degree of fit and product-type, cue congruency effect across these two variables would be moderated by donation quantifier, evidencing only in the concrete donation quantifier condition. This results pattern suggests that the cue congruency effect extends from contexts having two cues (Miyazaki et al. 2005) to contexts having three cues - in this case, degree of fit, donation quantifier, and product-type. This is a useful research extension.

\section{Cue congruency effect across planned versus impulse purchase contexts}

In Study 1, cue congruency effects in CRM were moderated by product type, i.e., evidenced in more hedonic contexts but not in less hedonic contexts. In Study 2, we have two objectives. First, we wish to replicate the key elements of Study 1 cue congruency results. Thus, we restrict our examination only to more hedonic products. Second, we examine whether cue congruency effects in CRM can also be moderated by purchase type-planned purchase versus impulse purchase.

Shopping for a product may be conceptualized as being planned versus on impulse (Lee and Kacen 2008; Rook 1987). Impulse buying is widespread, accounting for up to $80 \%$ of all purchases in certain product categories (Kacen and Lee 2002). However, impulse buying is not very well researched (Inman et al. 2009), and much of traditional research-including our Study 1 -has typically related to planned purchases. Given that the domain of impulse purchases is important and yet relatively unexplored, we consider how planned versus impulse purchases might impact cue congruency effect in CRM contexts.

Impulse purchases are a form of "unplanned purchases" that were not anticipated or planned before the consumer enters the store (Lee and Kacen 2008). Consumers making impulse purchases typically are less deliberative and more emotion-driven (Kacen and Lee 2002). Prior research indicates that such consumers are less likely to exhibit the negativity bias (Ahluwalia 2002). In such cases, either the negativity bias may attenuate, or reverse into the "positivity bias" (Ahluwalia 2002; p. 278). Hence, in impulse purchase contexts, it is quite possible that either (1) the negativity bias should

\footnotetext{
${ }^{4}$ We thank an anonymous reviewer for this observation.
} 
attenuate, implying no cue congruency effect, as the negativity bias underlies the cue congruency effect, or (2) there could be a positivity bias, leading to a "reverse" cue congruency pattern. In a reverse cue congruency pattern, purchase intentions should be lowest when both cues are congruent and individually do not increase purchase. Otherwise, due to the positivity bias, the presence of any positive cue should dominate other cues, and thus, in all other cases (either incongruent cues, or two congruent cues that both individually increase purchase), purchase intentions should be similar and higher.

Given that purchase-type impacts differences in the levels of negativity bias, and given that the negativity bias underlies the cue congruency effect, it follows that purchase-type should impact whether, and how, consumers exhibit cue congruency effect. In the planned purchase condition, we expect to replicate Study 1 results. However, in the impulse purchase condition, for various combinations of productcause fit and donation quantifier, we either do not expect across-cell differences, or we expect across-cell data patterns to reflect a reverse cue congruency pattern. Given that this investigation into impulse purchases is early and somewhat speculative, we do not present formal hypotheses but rather just proceed to examine the contrast between the planned purchase and the impulse purchase domains.

\section{Study 2}

\subsection{Pretest}

In Study 2, the three independent variables were product-cause fit, concrete versus vague donation quantifier, and planned versus impulse purchase environments. While the latter two variables could be easily manipulated via differences in the stimuli text, we ran a pretest to help determine how best to identify cases of high versus low product-cause fit. Given that we decided on a box of assorted cookies as a suitable (more hedonic) product, we ran a pretest to see if the causes Freedom from Hunger and The Nuclear Age Peace Foundation would be classified as high versus low fit (respectively). Fifty-nine undergraduate participants were asked which of the two charitiesFreedom from Hunger/The Nuclear Age Peace Foundation-had a higher/lower fit with a box of assorted cookies. As expected, over $90 \%$ respondents indicated that Freedom from Hunger (Nuclear Age Peace Foundation) had a higher (lower) fit with the focal product "cookies."

\subsection{Methods}

Undergraduate students ( $N=219$, females $=52.5 \%$, median age $=22$ years) were randomly assigned to a 2 (product-cause fit: high vs. low) $\times 2$ (donation quantifier: concrete vs. vague) $\times 2$ (purchase-type: planned vs. impulse) between-subjects study. In all cases, participants considered purchase of cookies, priced at \$10, with embedded CRM. Shopping type was manipulated by stating, "Imagine that you are entering your local supermarket with a list of items that you need to purchase on your shopping trip. One item on your shopping list is a box of assorted cookies" (for planned purchases), or "Imagine that you are entering your local supermarket and you notice a table display set 
up to sell a box of assorted cookies" (for impulse purchases). The manipulations for planned versus impulse purchase were consistent with Inman et al. (2009).

Product-cause fit was manipulated by associated cookie purchases with either Freedom from Hunger (high fit) or The Nuclear Age Peace Foundation (low fit). Donation quantifier was manipulated by stating that either $\$ 1$ (concrete amount) or "a portion of the purchase price" (vague amount) was going to the charity. The dependent variable, charity-attitude measures, and manipulation check questions for product-cause fit and donation quantifier were similar to Study 1. Finally, to check the planned/impulse purchase manipulation, we asked: "Did the scenario mention whether the box of assorted cookies was something that you needed to purchase on your shopping trip?" (yes/no).

\subsection{Results}

All participants responded to the manipulation check questions correctly. Furthermore, the charity Freedom from Hunger reflected a higher product-cause fit $(M=5.10)$, versus the Nuclear Age Peace Foundation $\left(M=3.16 ; F_{(1,217)}=90.46\right.$, $p<0.01)$. Also, attitude measures for Freedom from Hunger $(M=5.07)$ versus The Nuclear Age Peace Foundation $\left(M=4.77 ; F_{(1,217)}=1.54, p>0.05\right)$ were not significantly different. The above results suggested we operationalized our manipulations appropriately.

All main effects were significant $\left(F_{(1,211)}>8.4, p<0.05\right)$, with the main effects for product-cause fit and donation quantifier replicating findings of prior work (cited earlier). Also, the higher purchase intentions for planned purchases reflected the consumers' purchase precommitment. All two-way interactions were not significant $\left(F_{(1,211)}<3.1, p>0.05\right)$. Most important, there was a significant three-way interaction $\left(F_{(1,211)}=13.20, p<0.01\right)$. Hence, we examined results separately for planned purchases versus impulse purchases (Fig. 3).

In the case of planned purchases, purchase intention was highest for high product-cause fit and concrete donation quantifier $(M=6.36)$, with planned contrasts against other cells $\left(M_{s} 5.13-5.54\right)$ indicating significant differences, all cases, $F_{(1,211)}>4.6, p<0.05$. Furthermore, purchase intention was not significantly different across the other three cells, with planned contrasts indicating non-significant differences, all cases, $F_{(1,211)}<1$. These findings exactly mirror the cue congruency effect results in Study 1.

In contrast, in the case of impulse purchases, the pattern of means was reversed (viz. planned purchases). Specifically, purchase intention was lowest for low product-cause fit and vague donation quantifier $(M=2.59)$, with planned contrasts against other cells $\left(M_{s} 3.48-3.98\right)$ indicating significant dif- ferences, all cases, $F_{(1,211)}>5.2, \quad p<0.05$. Furthermore, purchase intention was not significantly different across the other three cells, with planned contrasts indicating non-significant differences, all cases, $F_{(1,211)}<1.8, p>0.1$. Study 2 results indicated that - in impulse purchase environments - consumer evaluations exhibit a reverse cue congruency pattern. That is, consumers have high-and similarevaluations for either high product-cause fit or concrete donation quantifier, and only exhibit low evaluations when faced with both low prod- uct-cause fit and vague donation quantifier. 


\section{Planned Purchase}

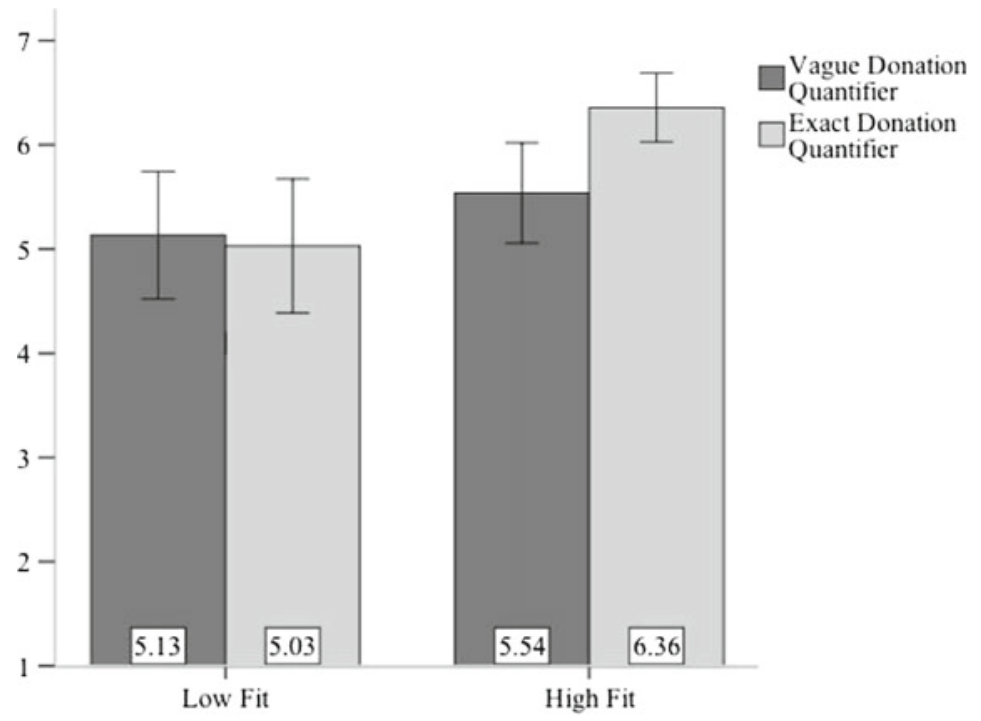

Impulse Purchase

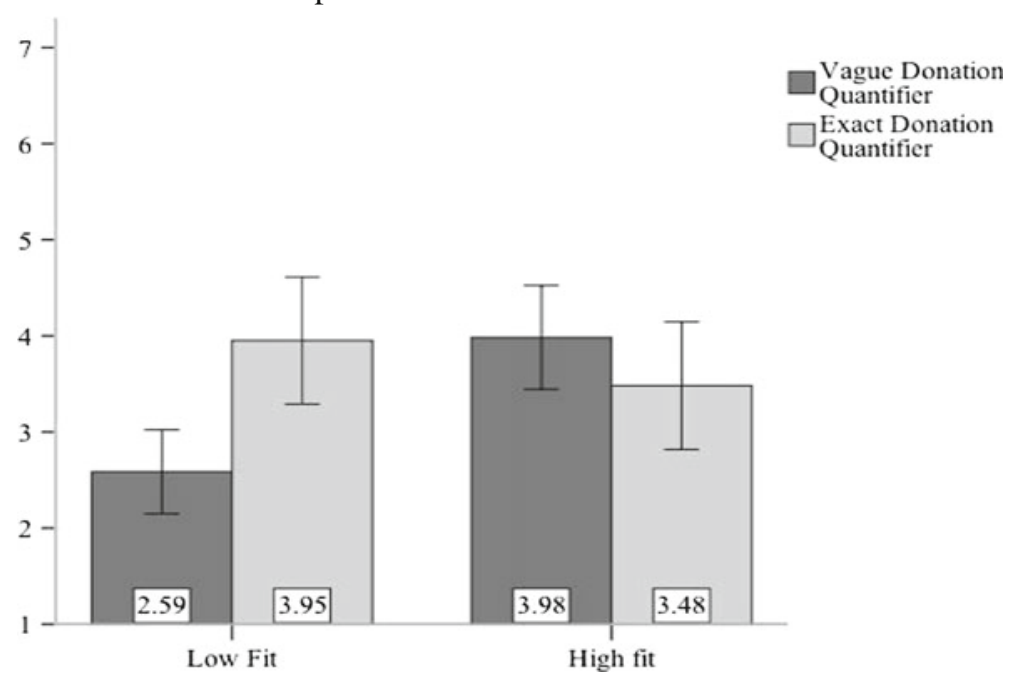

Fig. 3 Study 2 results

\section{Discussion and implications}

This research contributes to both theory and practice, with implications for research in CRM, product-cause fit, donation quantifier, the cue congruency effect, and impulse purchases. As regards theory contributions, this research is the first to examine the joint effects on consumers' evaluations across product-cause fit and donation quantifier in CRM contexts. The key result is that the positive interaction data pattern reflects the 
rather non-obvious and unique cue congruency pattern (and not any of the other possible interaction patterns).

Second, this research identifies important moderators of cue congruency effect. The most relevant product type difference, in CRM contexts, is the degree of hedonism (Strahilevitz and Myers 1998). Study 1 shows that the cue congruency effect evidences more only in more hedonic product contexts. This is consistent with other research indicating that CRM cues and cue congruency have greater efficacy in more hedonic product contexts, but we extend such research from (1) single cue contexts, to two cue contexts, and (2) from main effects, to interaction effects of a very specific type-cue congruency effects. Furthermore, we are the first (to our knowledge) to examine the impact of impulse purchase contexts (an increasingly important research domain) as a moderator of CRM outcomes. Study 2 shows that, in planned purchase contexts, the normal cue congruency pattern evidences. However, for impulse purchases, the cue congruency data pattern reverses. This research is thus the first to examine how the cue congruency effect evidences in CRM contexts and also identifies product-type and purchase-type as key moderators of this cue congruency effect.

Third, impulse purchase contexts are important but under-explored, and this research is an important extension that examines CRM in impulse purchase contexts. Study 2 results are perhaps reflective of the fact that impulse purchases are less deliberate and more emotion-driven, implying a positivity bias and not a negativity bias.

This research also contributes to practice. We provide a framework to think about how exactly to combine multiple cues to increase consumers' purchase intentions in CRM contexts. In more hedonic product CRM contexts, marketers should note that cue congruency effect is operant and should thus use congruent cues, i.e., cues which are mutually consistent in terms of their positive impact on consumers' purchase intentions.

Furthermore, significant amounts of purchases in supermarkets, grocery stores, and mass merchandisers are based on impulse, and this is the first research that gives retailers some guidance as to how to structure CRM campaigns in such impulse purchase contexts. Marketers just need to ensure they provide (at least) one positiveimpact cue, and this cue alone would be enough to drive consumer purchases.

Future research could proceed in multiple directions. First, researchers could further examine CRM contexts, looking at other moderators of the cue congruency effect, like individual differences in guilt proneness. For example, given that consumers experience increased guilt when making hedonic purchases, CRM efforts and associated cue congruency are more impactful when associated with hedonic purchases. Nevertheless, those chronically less prone to guilt (individual difference measure, Tangney 1990) may not experience increased guilt when making hedonic purchases and so would be less impacted by cue congruency. Second, researchers could take a thin sliver of the data in this paper and then do a more granular examination of process. For example, considering just impulse purchases, researchers may examine if the results vary across consumers who are high self-monitors and low self-monitors, or researchers might formally test if impulse purchase contexts truly reflect a context with positivity bias. Like other research that shows some novel effects, the true impact of this research may be more in the research it inspires.

Acknowledgments The authors acknowledge the financial support received from Walker College of Business Dean's Club at the Appalachian State University, which funded part of this research. 


\section{References}

Ahluwalia, R. (2002). How prevalent is the negativity effect in consumer environments? Journal of Consumer Research, 29(2), 270-279.

Batra, R., \& Ahtola, O. T. (1991). Measuring the hedonic and utilitarian sources of consumer attitudes. Marketing Letters, 2(2), 159-170.

Campbell, M. C., \& Goodstein, R. C. (2001). The moderating effect of perceived risk on consumers' evaluations of product incongruity: preference for the norm. Journal of Consumer Research, 28(3), 439-449.

Folse, J. A. G., Niedrich, R. W., \& Grau, S. L. (2010). Cause-relating marketing: the effects of purchase quantity and firm donation amount on consumer inferences and participation intentions. Journal of Retailing, 86(4), 295-309.

Herr, P. M., Kardes, F. R., \& Kim, J. (1991). Effects of word-of-mouth and product-attribute information on persuasion: an accessibility-diagnosticity perspective. Journal of Consumer Research, 454-462.

Inman, J. J., Winer, R. S., \& Ferraro, R. (2009). The interplay among category characteristics, customer characteristics, and customer activities on in-store decision making. Journal of Marketing, 73(5), 19-29.

Kacen, J. J., \& Lee, J. A. (2002). The influence of culture on consumer impulsive buying behavior. Journal of Consumer Psychology, 12(2), 163-176.

Khan, U., Dhar, R., \& Wertenbroch, K. (2005). A behavioral decision theory perspective on hedonic and utilitarian choice. Inside consumption: frontiers of research on consumer motives, goals, and desires, 144-165.

Kronrod, A., Grinstein, A., \& Wathieu, L. (2012). Enjoy! Hedonic consumption and compliance with assertive messages. Journal of Consumer Research, 39(1), 51-61.

Lafferty, B. A., Goldsmith, R. E., \& Hult, G. T. M. (2004). The impact of the alliance on the partners: a look at cause-brand alliances. Psychology \& Marketing, 21(7), 509-531.

Lee, J. A., \& Kacen, J. J. (2008). Cultural influences on consumer satisfaction with impulse and planned purchase decisions. Journal of Business Research, 61(3), 265-272.

Maheswaran, D., \& Chaiken, S. (1991). Promoting systematic processing in low-motivation settings: effect of incongruent information on processing and judgment. Journal of Personality and Social Psychology, 61(1), 13.

Miyazaki, A. D., Grewal, D., \& Goodstein, R. C. (2005). The effect of multiple extrinsic cues on quality perceptions: a matter of consistency. Journal of Consumer Research, 32(1), 146-153.

Nan, X., \& Heo, K. (2007). Consumer responses to corporate social responsibility (CSR) initiatives: examining the role of brand-cause fit in cause-related marketing. Journal of Advertising, 36(2), 63-74.

Okada, E. M. (2005). Justification effects on consumer choice of hedonic and utilitarian goods. Journal of Marketing Research, 43-53.

Olsen, G. D., Pracejus, J. W., \& Brown, N. R. (2003). When profit equals price: consumer confusion about donation amounts in cause-related marketing. Journal of Public Policy \& Marketing, 170-180.

Pracejus, J. W., \& Olsen, G. D. (2004). The role of brand/cause fit in the effectiveness of cause-related marketing campaigns. Journal of Business Research, 57(6), 635-640.

Pracejus, J. W., Olsen, G. D., \& Brown, N. R. (2003). On the prevalence and impact of vague quantifiers in the advertising of cause-related marketing (CRM). Journal of Advertising, 32(4), 19-28.

Rogers, S. C. (2001). Marketing strategies, tactics, and techniques: a handbook for practitioners. Greenwood Publishing Group, U.S.A.

Rook, D. W. (1987). The buying impulse. Journal of Consumer Research, 14(2), 189-199.

Schumpeter (2014). We want to be your friend. The Economist, http://www.economist.com/news/business/ 21595412-brands-are-finding-it-hard-adapt-age-scepticism-we-want-be-your-friend. Accessed 25 July 2014.

Strahilevitz, M. (1999). The effects of product type and donation magnitude on willingness to pay more for a charity-linked brand. Journal of Consumer Psychology, 8(3), 215-241.

Strahilevitz, M., \& Myers, J. (1998). Donations to charity as purchase incentives: how well they work may depend on what you are trying to sell. Journal of Consumer Research, 24(4), 434.

Tangney, J. P. (1990). Assessing individual differences in proneness to shame and guilt: development of the selfconscious affect and attribution inventory. Journal of Personality and Social Psychology, 59(1), 102-111.

Dr. Abhijit Biswas is also an Honorary Visiting Professor at Institute of Management Technology (IMT), Ghaziabad, India 